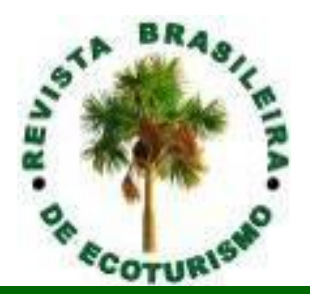

\title{
Ecoturismo, educação ambiental crítica e formação de sujeitos ecológicos: convergências e desafios ${ }^{1}$
}

\section{Ecotourism, critical environmental education and ecological subject's formation: convergences and challenges}

\author{
Patrícia Michelle Oliveira Freire, Fabiana Andrade Bernardes Almeida
}

RESUMO: A "questão ambiental" tem tomado a cena pública e estimulado diversos debates sobre as formas humanas de se relacionar com o mundo dito natural. O panorama contemporâneo de mal-estar perante a vida urbana conturbada tem impulsionado o desejo de "retorno à natureza" e, dessa maneira, as viagens a ambientes menos alterados têm sido procuradas e discutidas. Assim sendo, o ecoturismo vem ganhando destaque por sua proposta de se aliar ao elemento educacional a fim de superar a apreciação meramente contemplativa desses ambientes. Dessa maneira, o ecoturismo tem como ideal de sua prática a promoção de uma consciência ecológica amparada pela educação ambiental (EA). Entretanto, também é necessário relacionar o ecoturismo a temas como o consumo e a mercantilização da natureza, que culminam para que essa experiência perca seu caráter transformador e torne-se simplesmente mercadoria e espetáculo. Ademais, a EA possui diferentes vertentes de fundamentação e, assim, o ecoturismo pode basear-se em diferentes propostas educativas. A EA crítica, especificamente, apresenta-se como um projeto político-pedagógico que objetiva a formação de um sujeito (cons)ciente e capacitado a "ler e interpretar" o mundo ao seu redor, ou seja, o ambiente e as relações e conflitos inscritas nele. Dessa forma, como ação educativa, dedica-se a formação humana de um sujeito ecológico, um sujeito crítico que compreende o mundo e suas responsabilidades, assim como também age em respeito ao mundo. Então, estabelecidas as relações entre a EA e o ecoturismo buscouse analisar se o ecoturismo como prática consciente na "natureza", pode contribuir para a formação do sujeito ecológico fundamentado na EA crítica. Dessa maneira, tornou-se possível considerar a formação desse sujeito ecológico através da prática do ecoturismo apenas como uma "possibilidade". Ressaltamos, então, que o caminho para essa formação precisa fundamentarse na valorização da educação não-formal como parte legítima da formação educativa, buscando superar uma visão idealizada e superficial da natureza tanto na prática do ecoturismo, como na educação ambiental.

PALAVRAS-CHAVE: Ecoturismo; Educação Ambiental Crítica; Sujeito Ecológico. 


\section{ABSTRACT}

The "environmental issue" has taken the public scene and stimulated several debates regarding the human forms of relating with the so called natural world. The discommodity contemporary view relative to the troubled urban life has driven people to nurture a desire to "return to nature" and, for this reason, the travels to less altered natural environments has been sought and debated. Therefore, ecotourism has been gaining attention due to its proposal of allying visits to nature and education in order to go beyond a mere contemplative appreciation of the environment. Thus, ecotourism has aims at promoting ecological awareness supported by environmental education. However, it is necessary to associate the activity to topics such as consumption and trade of nature that result in the loss and transformation of the experience, turning the experience into mere merchandise and entertainment. Furthermore, environmental education is composed by different grounds of substantiation and, because of that, ecotourism practice can be based on a broad range of educational proposals. The critical environmental education presents itself as a political-pedagogical project that aims at the formation of an aware subject capable to "reads and interprets" the world around him, that is, the environment and the relations and conflicts contained in it. Therefore, as an educational action, it is dedicated to the human formation of an ecological subject, a critical being, that comprehends the world and his responsibilities as well as acts in respect to the planet. So, once established the relations between environmental education and ecotourism, we will assess whether ecotourism, as a conscious practice in "nature", can contribute with the formation of an ecological being based on a critical environmental education. By this way, it was possible to consider the formation of this ecological subject through ecotourism only as a "possibility". In this paper, we emphasize that the way for this formation must be based on the valorization of nonformal education as a legitimate part of the individual's formation, seeking to overcome an idealized and superficial vision of nature, both in ecotourism and in environmental education.

KEYWORDS: Ecotourism; Critical Environmental Education; Ecological Subject.

\section{Introdução}

A "questão ambiental" tem se tornado muito recorrente nos debates e nas discussões de diferentes campos do meio acadêmico e também da cena pública. Não poderia ser diferente nos estudos sobre o turismo, onde se viu crescer tais discussões a partir do aumento da procura do público por viagens para os ambientes ditos naturais. Dessa forma, dentre as modalidades do turismo que abrangem práticas nesses ambientes, o ecoturismo se destaca por sua proposta de aliar as viagens à ação educativa. Nesse sentido, ele buscaria superar a apreciação meramente contemplativa do meio e contribuir para uma sensibilização mais aprofundada do sujeito turista.

Assim sendo, o ecoturismo constitui-se a partir de premissas que buscam possibilitar uma (re)conexão com o meio onde há um predomínio de elementos físicos naturais, tais como vegetação nativa, ambientes serranos, dentre outros. Por conseguinte, é muito recorrente a afirmação de que a prática do ecoturismo tem como ideal a promoção de uma "consciência ecológica". Como a mudança de consciência está atrelada à formação dos sujeitos discutiremos aqui as possíveis relações entre o ecoturismo e a formação de um sujeito ecológico. 
Dessa forma, torna-se necessário pensarmos sobre os caminhos que podem permitir que essa formação se concretize. No âmbito do ecoturismo, é bastante ressaltada sua estreita relação com a educação ambiental, apontando-se com frequência a Lei 9.795/99 que dispõe sobre a Educação Ambiental $^{2}$ e estabelece a ação da educação ambiental não-formal por meio do ecoturismo. Nesse sentido, ressaltaremos aqui o caminho da educação ambiental para a possível construção dessa formação e trataremos sobre isso a partir da seguinte problemática central: A prática do ecoturismo estimula a formação de sujeitos ecológicos?

Doravante, abriremos espaço para entender as relações entre o ecoturismo e a educação ambiental (EA), ressaltando que entendemos a EA como uma prática pedagógica ampla que pode ser construída a partir de diferentes vertentes. Portanto, discutiremos alguns pontos de suas vertentes, centrando nossa discussão nos elementos da abordagem chamada crítica. Assim, nossa intenção será situar os campos de estudo do ecoturismo e da educação ambiental (crítica) e refletir acerca de suas relações. Buscaremos também explicitar algumas possibilidades, inconsistências e desafios para a aproximação entre o que é abordado pela literatura e o que é realizado nessa prática. Dessa forma, buscaremos contribuir para essa discussão a partir do arcabouço teórico apresentado, a fim de "proporcionar visão geral, de tipo aproximativo, acerca de determinado fato" (GIL, 2008, p. 27), neste caso, acerca dos temas supracitados para que se torne possível gerar contribuições para os estudos nos referidos campos do conhecimento.

\section{O Ecoturismo no mundo do Turismo}

A maioria dos pesquisadores do campo de estudo do turismo compreendem o seu surgimento a partir do contexto socioeconômico vinculado à Revolução Industrial. Na sociedade desse período histórico, o lugar central ocupado pelo trabalho também abriu espaço para o nascimento das noções de tempo livre e de lazer (BARRETO, 2014; CORIOLANO, 2006; KRIPPENDORF, 2001; OURIQUES, 2005). Segundo a historiografia do turismo, o turismo como fenômeno da modernidade se expandiu a partir do triunfo da sociedade industrial, nos séculos XIX e XX, e dos avanços dos meios de comunicações, de transportes e da conquista dos direitos trabalhistas que deram um novo contraste ao fenômeno (CORIOLANO, 2006). Assim, a atividade se beneficiou tanto do contexto socioeconômico (trabalho/remuneração e tempo livre $3 /$ lazer) instaurado neste período, como das inovações tecnológicas e das facilidades que nele foram produzidas (CORIOLANO, 2006; BARRETTO, 2014).

Ademais, podemos dizer que o turismo se encontra inserido e emaranhado junto à lógica capitalista de consumo e, nesta perspectiva, torna o tempo livre em oportunidade de lucro, já que possuindo tempo e dinheiro para praticá-lo é possível "fugir do cotidiano", "recuperar as forças", "desligar", "descansar", "relaxar" (KRIPPENDORF, 2001). Coriolano (2006) ainda ressalta que é a partir do estabelecimento da sociedade capitalista que se torna possível extrair lucro do tempo livre transformando-o em lazer e em turismo e moldando-os como oportunidade de negócio. 
Nessa sociedade de consumo, as concepções de turismo influenciadas pelo pensamento desenvolvimentista ganham força e "desenvolver" o turismo passa a dinamizar a economia, aumentar as divisas, estimular os negócios e gerar empregos (OURIQUES, 2005). Esse pensamento desenvolvimentista predominou em diferentes campos de estudos e, com ele, o conceito de desenvolvimento ganha unicamente caráter de crescimento econômico (ESTEVA, 2000, p. 66).

Assim, as visões unicamente econômicas do turismo ganharam força e impulsionaram o "turismo convencional" e a massificação do turismo ${ }^{4}$, principalmente a partir da década de 1960, quando "os empreendimentos turísticos passaram a representar a oportunidade de alavancar 0 desenvolvimento econômico" (OURIQUES, 2005, p. 15). Entretanto, segundo Cruz (apud CORIOLANO, 2006), o chamado "turismo de massa" não foi, necessariamente, acessível às massas. Isso porque o termo representa uma forma de organização da atividade turística que possibilitou o barateamento dos custos de viagem (que envolveu a interligação do agenciamento do turismo, dos transportes e dos meios de hospedagem), mas não necessariamente um aumento no acesso da maioria da população mundial à prática turística.

Portanto, ressalta-se que o turismo consiste em uma forma de lazer reservada aos indivíduos que possuem trabalho e, consequentemente, os privilégios que advém dele, ou seja, a remuneração e o tempo livre. À vista disso, afeta também as relações trabalhistas, podendo levar à precarização do trabalho e a relações de servilismo e dependência (OURIQUES, 2005). Ademais, tem impacto no próprio espaço geográfico, reorganizando-o à sua vontade e transformando-o em produto de consumo, produzindo "espaços altamente estandardizados e controlados pelas redes mercantis transnacionais" (CORIOLANO, 2006, p. 217).

Todavia, é necessário esclarecer que o fenômeno turístico não se restringe apenas às questões econômicas. Segundo Pires (2002), as abordagens reducionistas foram alvo de críticas a partir do fim dos anos 1970, quando após o auge vivenciado pelo turismo convencional, evidenciaram-se as consequências negativas geradas pela atividade e o impacto danoso nas comunidades anfitriãs, seja em sua estrutura social e econômica, como também em sua esfera ambiental.

Esse mesmo cenário também deu destaque ao conceito de "desenvolvimento sustentável" 5 no terreno dos estudos turísticos ${ }^{6}$. Neste momento, surgiram abordagens que buscavam conceber uma forma alternativa de turismo que fosse capaz de integrar outros elementos da atividade (social, cultural, ambiental) em sua análise e interpretação. Segundo Ouriques (2005), a partir da associação entre desenvolvimento sustentável e turismo foi possível observar um panorama em que a atividade é vista como grande alternativa para a sustentabilidade, sendo referida como "indústria sem chaminés".

Para o autor, essa denominação seria uma forma de demonstrar a possibilidade de conciliar aspectos econômicos com ecológicos. Entretanto, em sua compreensão, a associação do turismo à sustentabilidade não altera 
o caráter da atividade. Para ele, a visão que concebe o discurso "sustentável" promovido pelo turismo se esquece do "[...] caráter de consumo de espaço da atividade turística, já que o próprio meio ambiente é consumido por meio da recreação" (OURIQUES, 2005, p.19). Além disso, também ressaltamos que, em muitos contextos, o termo desenvolvimento sustentável foi sendo utilizado simplesmente como forma de "sustentar" o pensamento desenvolvimentista já conhecido, mostrando poucas mudanças e pouca preocupação com os aspectos natural e social de modo geral (ESTEVA, 2000). Portanto, destacamos aqui as contradições presentes na concepção do discurso sustentável, ressaltando que elas também aparecem na associação deste tema ao fenômeno turístico.

Por tudo isso, faz-se necessário ressaltar que o turismo é um fenômeno complexo e multifacetado (CORIOLANO, 2006). Dessa forma, é premente explicitar que sua redução a apenas uma ou outra perspectiva seja ela, econômica, geográfica, social, cultural, ecológica, estatística ou outra - limita a reflexão sobre o fenômeno. Assim, entendemos que é essencial a busca de uma reflexão que leve em conta a "complexidade da atividade analisada nas diversas perspectivas das visões disciplinares, que, contudo, interconectadas podem tornar a explicação do fenômeno mais lúcida e a atividade considerada mais séria e mais respeitada" (CORIOLANO, 2006, p. 46).

Ademais, lembramos que a redução do fenômeno turístico peca por negligenciar seu caráter humano e social. Panosso Netto (2005, p. 30), ao analisar o turismo por uma perspectiva filosófica, reitera que o fenômeno turístico "[...] não pode ser fragmentado para estudo, devendo ser visto como um todo conexo. Assim, cada ser experiencia e historicia de maneira diferente o seu viver que envolve o turismo". Por isso, o autor considera o turista como um sujeito que se constrói continuadamente por suas experiências (passadas, presentes e futuras), enquanto o fenômeno turístico compõe as relações de intercâmbio entre os aspectos objetivos e subjetivos da experiência do sujeito turista. Dessa forma, diferencia-se o fato turístico do fenômeno turístico.

Panosso Netto (2005) ressalta que o fato turístico é composto pelos elementos objetivos dessa experiência, como a infraestrutura física e as empresas do setor. Assim, são elementos materiais sem vida que ganham valor a partir da interação humana pelo seu uso. Já o fenômeno turístico existe pela interação do sujeito turista com o fato turístico e, para o autor, o sujeito dos estudos do turismo "[...] é o responsável único pela configuração do que chamamos fenômeno turístico" (PANOSSO NETTO, 2005, p.31). Dessa forma, visões como essa passaram a ser valorizadas no contexto de novas discussões sobre o turismo perante a necessidade de contraposição ao modelo hegemônico instaurado.

Nesse cenário, iniciam-se discussões e reflexões para busca de uma prática turística que apresente uma preocupação sociocultural e ambiental com os habitantes e o destino. Paulo dos Santos Pires (2002, p. 36) ressalta que neste momento "[...] se desencadeiam as manifestações de descontentamento com a situação e que questões como os custos e benefícios do turismo para a economia, a sociedade e o ambiente, antes 
negligenciadas, começam a ser tratadas". Neste contexto, a concepção de "turismo alternativo" vai ganhando forma a partir de eventos que abordaram a temática7 e que possibilitaram que fossem "concebidas novas ideias $e$ princípios para a reorientação da atividade em nova ordem ética" (PIRES, 2002, p.37). O autor ainda cita os movimentos das próprias comunidades onde o turismo convencional se expandiu, ressaltando o posicionamento dos próprios nativos que denunciaram a "invasão turística" de seus territórios e se mobilizaram a favor do "desenvolvimento moderado e auto-sustentado do turismo" (PIRES, 2002, p.38).

Dessa maneira, no início dos anos 1980, esse "turismo diferente" ganhou forma sendo, inclusive, influenciado pela conjuntura histórica que marcou o mundo nos anos 1960 e 1970 (PIRES, 2002). Os movimentos e manifestações sociais e culturais deste período emprestaram seu caráter contestatório a essas discussões e revelam uma "[...] relação de contemporaneidade histórica e, ainda, de identidade filosófica desses acontecimentos, no sentido do seu significado transformador das relações sociais e de mudança de mentalidades na perspectiva cultural da trajetória humana" (PIRES, 2002, p.43).

Assim sendo, o turismo alternativo apresentou-se como uma opção para a construção de melhores práticas turísticas. Ressaltamos, porém, que recorrendo à literatura, é possível encontrar diferentes conceituações para o termo. Encontramos, por exemplo, definições com foco nas características sociais promotoras de integração (EADINGTON; SMITH apud PIRES), com enfoque na figura do turista (KRIPPENFORF, 2001) e até voltando-se para os aspectos empresariais (DERNOI apud PIRES, 2002).

Neste sentido, segundo Pires (2002), o turismo "alternativo" também recebe sua crítica visto que na medida em que foi se tornando concreto, também foi perdendo seu conteúdo conceitual e sua coesão. Por tudo isso, constatamos a necessidade de conceituar o "turismo alternativo" de maneira coerente aqui. Por isso, destacaremos o modelo de classificação apresentado por Stephen Wearing e John Neil (2001). Criado por Mieczkowski ${ }^{8}$, este modelo abrange o turismo em duas categorias amplas: o turismo de massa convencional (TMC) e o turismo alternativo (TA). A partir dessa classificação, Mieczkowski define o turismo alternativo como uma categoria genérica flexível, e Wearing e Neil (2001) utilizam essa classificação para definir o turismo alternativo:

[...] como formas de turismo que demonstram ser coerentes com os valores natural, social e comunitário e que permitem que tanto hospedeiros quanto hóspedes desfrutem uma interação positiva e conveniente, e compartilhem experiências" (WEARING; NEIL, 2001, p.4).

Assim sendo, de acordo com Wearing e Neil (2001, p. 5), o ecoturismo pode ser considerado uma prática de turismo alternativo, já que "pode ser geralmente descrito como um turismo interpretativo, de mínimo impacto, 
discreto, em que se busca a conservação, o entendimento e a apreciação do meio ambiente e das culturas visitadas".

Segundo estes autores, Hector Ceballos-Lascuráin é considerado o primeiro a abordar a prática ecoturística, quando em 1981 utilizou o termo turismo ecológico, passando em 1983 para a sua forma reduzida ecoturismo. Esse mesmo autor definiu o termo em 1987 pela primeira vez como "uma forma de viagem na qual o ambiente natural é o foco principal" (WEARING; NEIL, 2001, p. 6). Fennell (2002, p. 42) também cita Ceballos-Lascuráin como precursor ao abordar o ecoturismo, porém, remonta o termo aos trabalhos de Hetzer em 1965, quando este autor utilizou o termo "para explicar o intrincado relacionamento entre os turistas e os meio ambientes e culturas nos quais eles interagem".

Dessa forma, podemos apontar que a concepção do ecoturismo alinhase ao cenário sociocultural vivenciado a partir dos anos 1960 e 1970, quando a "questão ambiental" ganha espaço na cena pública e o movimento ecológico ganha destaque. Segundo Pires (2002), a partir dos anos 1980, as entidades e organizações voltadas para as causas ambientalistas procuraram maneiras de mobilizar o grande público e, assim, fundamentou-se uma interface entre ecoturismo-ambientalismo. Essas entidades e organizações investiram, então, no ecoturismo como "alternativa de instrumentalização de suas ações voltadas para a proteção dos recursos naturais e para o desenvolvimento de regiões economicamente deprimidas" (PIRES, 2002, p. 63).

O ecoturismo foi, então, concebido como uma forma de turismo alternativo que possui princípios específicos (WEARING; NEIL, 2001). Esses princípios variam de acordo com a concepção de cada autor, mas dentre eles, destacam-se: o interesse na natureza, a contribuição à conservação, o apoio em parques e áreas protegidas, o benefício às populações locais em longo prazo, a educação e o estudo, o baixo impacto/não predatório, a ética/responsabilidade, a gestão, a sustentabilidade, o usufruto/apreciação, a cultura e a pequena escala (FENNEL, 2002). Ademais, assim como no ecoturismo, existem outras práticas de turismo que envolvem o ambiente físico natural, como por exemplo, o turismo baseado na natureza ou turismo na natureza. Sendo assim, encontra-se na literatura o esforço de diversos autores (ZIFFER, 1989; GOODWIN, 1996; WEARING; NEIL, 2001; FENNEL, 2002) para diferenciar o turismo baseado na natureza do ecoturismo.

Wearing e Neil (2001) enfatizam que no "turismo baseado na natureza" a natureza é parte da experiência, entretanto, não é a motivação fundamental da prática (como por exemplo, o turismo para observação de pássaros). Já Fennell (2002) ressalta que o ecoturismo possui princípios específicos, como - componente educativo e de sustentabilidade e a natureza ética da experiência, além de lembrar que o turismo na natureza compõe uma gama de modalidades mais ampla. Dessa forma, seu enfoque é abrangente e sua prática restringe-se ao uso dos recursos naturais como "pano de fundo", sem necessariamente explicitar a preocupação ou a interação direta com o meio ambiente. Assim sendo, é possível encontrar diversos enfoques para o ecoturismo na literatura, o que acabou gerando conceituações muito 
abrangentes do termo (FENNELL, 2002, p. 47). Portanto, destacaremos aqui a conceituação proposta por Wearing e Neil (2001) que apresenta quatro elementos fundamentais para a prática ecoturística.

O primeiro elemento citado pelos autores é o deslocamento para o meio físico natural - ou seja, ambientes menos alterados ou menos urbanizados - e a motivação como o segundo elemento, sendo que as viagens ecoturísticas têm "o fim de estudar, desfrutar ou prestar ajuda voluntária com respeito à flora, à fauna, à geologia e ao ecossistema de uma área - assim como às pessoas (os guardiões) que vivem na vizinhança" (SWANSON apud WEARING; NEIL, 2001, p. 11). Como terceiro elemento, os autores ressaltam a contribuição do ecoturismo para a conservação da natureza. Segundo eles, essa contribuição se dá a partir do despertar da consciência e do respeito pelo meio físico natural nos visitantes que, encontrando-se em contato com essas áreas, têm a oportunidade de perceber sua importância. Por último, temos o papel educativo da prática, em que o ecoturismo é apresentado como "um veículo para o aumento da compreensão dos valores ambientais, além de uma atividade que surgiu devido à mudança fundamental no modo como a natureza é vista pela sociedade" (WEARING; NEIL, 2001, p. 12).

\section{A Educação Ambiental e o sujeito ecológico}

O contexto da formação do sujeito ecológico apoia-se em uma concepção socioambiental promovida pela EA crítica ${ }^{9}$, no qual é possível apreender as questões ambientais em seu caráter científico, mas também em suas relações com o mundo sociopolítico. Neste sentido, a EA crítica é "herdeira direta do debate ecológico e está entre as alternativas que visam construir novas maneiras de os grupos sociais se relacionarem com o meio ambiente" (CARVALHO, 2008, p.51). Assim, ela também se apoia no movimento ecológico/ambientalista que ganhou forças a partir das décadas de 1960 e 1970. A atmosfera de contestação deste período é marcada pelo reconhecimento da denominada "crise ambiental" na esfera pública, também em seus termos sociais e políticos.

Por isso, a Educação Ambiental (EA) representa uma forma de ação educativa pensada para engendrar uma reflexão a respeito desta crise ambiental. Entretanto, como em todos os campos de estudo, a Educação Ambiental não se fundamenta de uma maneira única e é pensada por diferentes áreas do conhecimento. Portanto, possui vertentes distintas de fundamentação e, por isso, é necessário ressaltarmos aqui os fundamentos da EA que nos traz a concepção de sujeito ecológico.

Usualmente, somos acostumados a normalizar uma visão da natureza entendida como "vida selvagem", "vida biológica", "natureza intocada", ou seja, uma visão naturalista. Entretanto, precisamos nos lembrar que essas linhas de pensamento, apesar de dominantes na sociedade, não são únicas, mas apenas traduzem certa visão específica de "natureza" (CARVALHO, 2008). Segundo Carvalho (2008), essa visão prioriza uma noção de meio ambiente reducionista, caracterizado apenas pelos domínios biológicos e físicos e, 
assim sendo, independente das suas relações ou interações com o mundo humano (cultural) que, muitas vezes, é compreendido apenas como perturbador do meio natural, problemático ou nefasto. De acordo com Gustavo Ferreira Lima (2009), essa corrente de pensamento deu origem à EA conservacionista e foi fortemente influenciada pelo campo de estudos das ciências naturais.

Assim sendo, ressaltamos que a EA "surge em um terreno marcado por uma tradição naturalista” (CARVALHO, 2008, p.37) e, por isso, também tem sua linha de construção com raízes aliadas ao paradigma científico moderno e sua normatividade técnico-científica. Este paradigma científico dominante, como mostra Boaventura de Sousa Santos (1988), reinou a partir da revolução científica no século XVI até fins do século XX e, com isso, podemos observar suas heranças presentes na concepção da EA conservacionista.

Santos (1988) destaca que a distinção natureza/ser humano tão presente durante a revolução científica contribuiu para novas formas de distinção formuladas no campo científico, como "a distinção natureza/cultura e a distinção ser humano/animal” (SANTOS, 1988, p.8). São estas distinções que Carvalho (2008) busca questionar ao destacar a abertura do campo científico para a construção do saber educativo e ambiental amparado em uma visão compreensiva ${ }^{10}$. Essa abertura ocorreu como resultado da crise do paradigma científico moderno que se deu a partir da "identificação dos limites, das insuficiências estruturais do paradigma11" (SANTOS, 1988, p.8). Dessa forma, o campo científico foi sendo repensado e, com isso, foi se abrindo para novas concepções da ciência e da sua prática a partir de "uma reflexão de tal modo rica e diversificada que, melhor do que qualquer outra circunstância, caracteriza exemplarmente a situação intelectual do tempo presente" (SANTOS, 1988, p. 10).

Assim sendo, este quadro possibilitou no campo ambiental, a concepção da EA crítica que busca aceitar o desafio de "transitar entre os múltiplos saberes: científicos, populares e tradicionais, alargando nossa visão do ambiente e captando os múltiplos sentidos que os grupos sociais atribuem a ele" (CARVALHO, 2008, p.125). Por isso, a EA crítica situa-se a partir da emergência de um novo paradigma ${ }^{12}$, de uma nova revolução científica bem diferente da que aconteceu no século XVI. Entendemos que as concepções da EA conservacionista e crítica $^{13}$ são distintas em seus planos científico, ambiental e social, além de em suas orientações pedagógicas.

No âmbito dessas práticas educativas, a EA conservacionista prioriza uma postura conteudista em que a transmissão de informações de cunho biológicos/ecológicos tem destaque, além da "[...] transmissão de condutas ecologicamente corretas e a sensibilização individual para a beleza da natureza, levando-nos a mudar de comportamento" (LOUREIRO, 2007, p.67). Além disso, a EA conservacionista também carrega um caráter tecnicista que traz "[...] a pretensão positivista de uma neutralidade ideológica e inalcançável e o utilitarismo de uma razão que instrumentaliza a exploração e dominação dos seres humanos e da natureza" (LIMA, 2009, p.155), assim como as limitações causadas pela dissociação dos aspectos biológicos/ecológicos dos aspectos sociais/políticos, que causam "[...] a fragmentação e a perda da 
interdependência inerente à existência; o reducionismo e o objetivismo que acabam sacrificando tanto os aspectos não racionais da realidade quanto toda a subjetividade humana" (LIMA, 2009, p.155).

Já a EA crítica busca romper com essa abordagem individualista, reprodutivista e comportamentalista, assumindo uma perspectiva interdisciplinar que se ampara em diferentes saberes e disciplinas ultrapassando, assim, a especialização do conhecimento (CARVALHO, 2008). Essa perspectiva da EA crítica abordada através da visão socioambiental é um desafio necessário para compreender as complexidades da "questão ambiental". Dessa maneira, a EA crítica traduz a ambição de uma mudança ao modelo pedagógico disciplinar instituído, para que se torne possível ampliar as perspectivas de construção do aprendizado pessoal e institucional (CARVALHO, 2008). Por isso, essa ação educativa não pode ser apenas uma decodificação, ou seja, uma transmissão de dados, informações e explicações, já que como nos mostra Paulo Freire (1996): "ensinar não é transferir conhecimento, mas criar as possibilidades para a sua própria produção ou a sua construção" (FREIRE, 1996, p.12).

Por conseguinte, segundo Carvalho (2008), a EA crítica busca criar a possibilidade de novas leituras e interpretações do mundo e do outro, além de novas formas de se relacionar com o mundo que chamamos "natural". Com isso, lembramos que nossa leitura e interpretação do mundo são constantes e particulares, visto que são determinadas em grande parte pelo nosso contexto social, histórico e cultural de vida, como nos mostra a pedagogia freireana. Dessa forma, através dessa prática educativa torna-se possível a abertura para novas maneiras de ler e interpretar o mundo, tornando possível novas visões, novas compreensões e novas versões das realidades e da construção do mundo à nossa volta (CARVALHO, 2008). Portanto, Carvalho (2008, p.156157) ressalta que

[...] o projeto político-pedagógico de uma EA crítica poderia ser sintetizado na intenção de contribuir para uma mudança de valores e atitudes, formando um sujeito ecológico capaz de identificar e problematizar as questões socioambientais e agir sobre elas.

Segundo Carvalho (2008), esse sujeito ecológico é aquele que engloba os princípios do ideário ecológico, ou seja, ele representa um ideal de ser ${ }^{14}$ que, na medida em que é trabalhado e internalizado pelo sujeito, se torna um parâmetro orientador das decisões e escolhas de sua vida. Assim sendo, as pessoas que se propõem a aderir a esse ideário vão, no seu dia-a-dia, incorporando esses princípios em suas práticas e relações. Esta referência a um "modelo ideal" não significa, de forma alguma, a existência de um modelo exato ou um código normativo restrito que deve ser seguido às riscas.

Carvalho (2008) aponta que esse sujeito ecológico pode se apresentar a partir de diferentes facetas, ou seja, respeitando as características pessoais de cada um. O que o caracteriza mais fortemente é seu conjunto de valores e 
crenças, assim como sua "postura ética de crítica à ordem social vigente" (CARVALHO, 2008, p.67). Esta crítica deve sempre ser efetivamente uma autocrítica, já que

\begin{abstract}
Crítica sem autocrítica é problematizar o movimento da vida querendo ficar de fora [...] não basta apontar os limites e contradições e fazer denúncias. É preciso assumir com tranquilidade que vivemos em sociedade e que, portanto, mesmo quando buscamos ir além da realidade na qual estamos imersos, acabamos muitas vezes repetindo aquilo que queremos superar. [...] Admitir erros, incertezas, inquietações e dificuldades é inerente ao processo de transformação da realidade e constituição dos sujeitos, sendo indispensável para refletirmos sobre o que fazemos, o que buscamos e quais são os caminhos que estamos trilhando (LOUREIRO, 2007, p.67-68).
\end{abstract}

Ademais, precisamos ressaltar que em nossa sociedade de massa, é muito frequente que o indivíduo se veja abarrotado por condicionantes homogeneizadoras e ameaçado a cumprir um papel de reprodução — sem crítica e sem voz. Por isso, se torna necessária, mais do que nunca, a resistência que, no sentido apresentado aqui, se dá pela formação do sujeito.

Para dialogar nessa discussão sobre a formação do sujeito, apresentaremos a visão do autor francês Alain Touraine (1998). Segundo ele, o indivíduo pressionado por essa cultura de massa - com seu fluxo incessante de informações, produtos, serviços e bens - tem como alternativa de resistência seu esforço "[...] para transformar experiências vividas em construção de si como ator" (TOURAINE, 1998, p. 23). Touraine (1994; $1998)^{15}$ caracteriza o momento atual como um período de dissociação dos universos que compõem a nossa existência. Assim, o autor aponta que, a partir do estabelecimento da sociedade industrial, vivemos um panorama de crescente autonomia da atividade econômica e enfraquecimento das forças políticas e sociais ${ }^{16}$ de nossa sociedade (TOURAINE, 1998). Esse quadro acabou por acarretar a degradação do universo da objetividade (técnicas) em puro mercado e a fragmentação do universo da subjetivação (identidades culturais) nos perigos do comunitarismo autoritário ${ }^{17}$ (TOURAINE, 1998).

Neste sentido, a formação do sujeito se dá perante a ameaça da fragmentação de si e do seu desejo de resistência à degradação desses universos. Essa formação exige consciência da situação que vivemos, — ou seja, exige a não alienação e a distância do narcisismo - para que seja possível a afirmação de si mesmo e, a partir disso, seu direcionamento para a ação - a vontade e capacidade de agir (TOURAINE, 1998). Ademais, o autor ressalta enfaticamente que para que a resistência do indivíduo tenha efeito e constitua a real formação do sujeito, ela não pode ser apenas reflexiva, interiorizada, como um projeto de auto aperfeiçoamento. Para ele, esse processo envolve a ação, o esforço, o trabalho. Ou seja, só é possível conceber o sujeito na ligação entre a experiência pessoal e a ação coletiva. 
Assim, ele nos afirma que a possibilidade do sujeito se formar existe apenas onde "se manifesta uma ação coletiva de construção de um espaço, ao mesmo tempo social, político e moral, de produção da experiência individual e coletiva" (TOURAINE, 1998, p.98).

Alain Touraine (1998) destaca ainda o papel das relações entre sujeitos como elemento essencial para a sua própria formação. O sujeito deve ter consciência de que para construir a ação coletiva necessária à sua luta, é preciso buscar apoio no outro, no seu igual, a partir da construção de uma relação de compreensão e de diálogo. É justamente por esse papel central da relação entre sujeitos que precisamos negar veemente a ideia de que o sujeito é um "individuo livre e senhor das suas escolhas, guiado pelo próprio interesse e pelo seu prazer" (TOURAINE, 1998, p.82). Esta noção é muito mais próxima de um individualismo narcisista. Assim sendo, a formação do sujeito na nossa sociedade é sempre um desafio diário já que somos ameaçados com os perigos desse individualismo narcisista e do egoísmo ou da introspecção obsessiva.

Dessa forma, podemos ver nas ideias de Alain Touraine (1994;1998) sobre a formação do sujeito muitos elementos em comum referentes ao sujeito ecológico, afinal, ele é antes de tudo, sujeito de si. Entendemos, assim, que o resgate à formação do sujeito abordada pela sociologia touraineana nos dá algumas bases sobre a gênese de sua formação, visto que nos possibilita contextualizar a existência e a atuação desse sujeito na sociedade como um todo. Além disso, traz à tona os elementos iniciais para sua concretização, como a dupla recusa aos universos em conflito - a resistência -, o esforço contínuo e diário — o trabalho constante - a importância da relação com outros sujeitos - o diálogo - e, principalmente, a centralidade dada à ação coletiva - por exemplo, os movimentos sociais e culturais - para essa formação.

Ademais, visto que representa uma utopia norteada por valores éticos, a formação do sujeito ecológico pode parecer um esforço inalcançável. Entretanto, não se deve ignorar a sua importância para construção da ação coletiva capaz de criar "um espaço de liberdade, de invenção e imaginação" (TOURAINE, 1998, p. 79). Por isso, é primordial ressaltar que o sujeito ecológico "tem valor fundamental para animar a luta por um projeto de sociedade bem como a difusão desse projeto" (CARVALHO, 2008, p.67). Além disso, vivemos tempos de desânimo e acomodamento em que perdemos a confiança nas instituições políticas e sociais declinadas. Mediante este panorama, a concepção do sujeito ecológico "carrega esperanças e apostas na possibilidade de mudanças tanto em termos coletivos [...] [quanto em] transformações na vida pessoal" (CARVALHO, 2008, p.69).

Assim sendo, para Carvalho (2008), a EA crítica possibilita o surgimento desse sujeito ecológico, pois tem como principal aspiração a constituição de uma atitude ecológica. Essa atitude ecológica é definida "como a adoção de um sistema de crenças, valores e sensibilidades éticas e estéticas" (CARVALHO 2008, p.177). A autora aponta também a necessidade da diferenciação entre atitudes e comportamentos. Há no âmbito 
da educação ambiental propostas pedagógicas que priorizam uma visão em que

[...] a tarefa educativa seria a de transmitir os conhecimentos corretos, de informar e sensibilizar as pessoas, apelando para o seu bom senso moral, o que em poucas palavras pode ser sintetizado como a mudança dos comportamentos humanos em sua relação com o ambiente (LIMA, 2009, p.155).

Essa abordagem serve como orientação pedagógica para a EA conservacionista, já mencionada anteriormente. Segundo Loureiro (2007), é uma abordagem que não leva em conta as complexidades dos processos de aprendizagem, assim como desconsidera a importância da mudança no nível de atitudes e de valores no sentido social amplo, não apenas comportamentos pontuais.

Essa dissonância entre comportamentos e atitudes representa, para Carvalho (2008), um dos maiores desafios da EA que se propõe crítica. A autora reconhece que, pela complexidade do processo de aprendizagem, essa visão comportamentalista não necessariamente garante a formação da atitude ecológica, ou seja, de um "um sistema de valores sobre como relacionar-se com o ambiente, sistema que será internalizado como uma visão de mundo orientadora dos posicionamentos do sujeito na escola e em outros espaços e circunstancias de sua vida" (CARVALHO, 2008, p.180).

Portanto, entendemos que o comportamentalismo implica restrição da existência do sujeito a uma individualidade privada, "dissociando-a do campo da ação política e da cidadania" (LIMA, 2009, p.155). Assim sendo, em sua aspiração mais ousada, a formação do sujeito ecológico pela EA crítica busca alcançar "transformações significativas no sentido da construção de novo padrão social, de novo pacto civilizatório, desejado por um ideário ecológico emancipador" (CARVALHO, 2008, p.183-184). Para isso, entendemos que é essencial que a prática educativa do sujeito ecológico procure superar uma concepção comportamentalista da aprendizagem. Assim, é importante que se construa priorizando tanto a dimensão cognitiva quanto a afetiva na formação de uma atitude ecológica e abarque os elementos éticos e estéticos da formação do sujeito, visto que

[...] transformar a experiência educativa em puro treinamento técnico é amesquinhar o que há de fundamentalmente humano no exercício educativo: o seu caráter formador. [...] o ensino dos conteúdos não pode dar-se alheio à formação moral do educando (FREIRE, 1996, p. 16).

\section{O ecoturismo: suas possibilidades e seus desafios}

Conforme abordamos até aqui, o ecoturismo apresenta-se como uma possibilidade de prática da educação ambiental não-formal. Apresentamos algumas premissas básicas da atividade ecoturística, entretanto, gostaríamos também de abordar de maneira mais aprofundada algumas de suas influências, contradições e desafios. Para isso, recordaremos rapidamente 
alguns pontos importantes da relação sociedade-natureza, que nos aponta alguns fatores para contextualizar a aproximação do ecoturismo à sua inspiração filosófica.

A relação entre a sociedade e a natureza não-humana foi construída a partir de uma visão antropocêntrica e recebeu grande influência das religiões e da revolução científica, levando assim a um panorama que "desvalorizou a natureza e transformou-a em objeto" (WEARING; NEIL, 2001, p.18). Os valores associados a essa visão de mundo influenciam fortemente as relações entre a sociedade e a natureza. Essa conjuntura levou à valoração instrumental ${ }^{18}$ da natureza que é base para uma ética do "uso", onde a natureza e o modo como nos relacionamos com ela, são caracterizados como "[...] um conjunto de recursos que a humanidade é livre para empregar às suas próprias e variadas finalidades" (WEARING; NEIL, 2001, p.17).

Essa ética de "uso" é forte na visão antropocêntrica dominante e suas justificativas instrumentais para a preservação da natureza ${ }^{19}$. Em contraponto a essa visão, Wearing; Neil (2001) apresentam a (re)emergência da filosofia ecocêntrica, representando a valoração intrínseca ${ }^{20}$ que fundamenta a ética "da" natureza. Essa ética "sustenta que as entidades não humanas são de valor igual ao da espécie humana" (WEARING; NEIL, 2001, p.17). Assim, ela ganha espaço a partir das décadas de 1960 e 1970, quando despontam questionamentos ao antropocentrismo como sistema de valores (WEARING; NEIL, 2001).

Dentre as linhas de pensamento dessa perspectiva ecocêntrica, destacaremos aqui a ecologia profunda por sua possível relação com 0 ecoturismo. Essa corrente defende uma visão filosófica "que acredita num entendimento holístico da natureza, em que o ser humano, por meio do Eu, está intrinsecamente conectado com todas as formas de vida" (WEARING; NEIL, 2001, p.21). A noção de interconexão entre as espécies é inspirada pela hipótese GAIA de James Lovelock (1988). Para Lovelock, o planeta é entendido como um organismo vivo onde todas as espécies e o meio em que vivemos estão entrelaçados como um sistema único (WEARING; NEIL, 2001, p.21). Dessa forma, apesar de sermos capazes de afetar desproporcionalmente esse organismo, somos simplesmente uma parte desse sistema.

Ademais, para a ecologia profunda não há divisão ou fronteira entre 0 humano e o natural, ou seja, "o Eu envolve todo o mundo em torno, e a natureza torna-se uma extensão de nós mesmos" (MATHEWS apud WEARING; NEIL, 2001, p.21). Essa visão promove, então, uma relação profunda de harmonia e respeito a todas as formas de vida do planeta, valorizando-as intrinsecamente. Segundo Wearing e Neil (2001), reconhecer e nutrir nossa interrelação com essas formas de vida, para os ecologistas profundos, contribui para que tenhamos consciência de nosso impacto no planeta.

Por fim, a filosofia da ecologia profunda traz também uma aspiração à transformação de nossa sociedade, visto que a partir do reconhecimento do valor intrínseco de todas as existências (humanas e não-humanas) busca-se construir "uma "consciência ecológica", que alcança sua expressão mais 
completa em um "mundo ético"” (WEARING; NEIL, 2001, p.22). Assim, encontramos nessa filosofia uma crítica ao sistema econômico vigente e ao modo de vida instituídos.

Para Wearing e Neil (2001, p. 30), o ecocentrismo apresenta-se como inspiração ao ecoturismo no sentindo em que afirma que as áreas naturais "[...] devem continuar existindo, pois possuem valor intrínseco". Dessa forma, tal inspiração possibilita a concepção de um ecoturismo que impulsione uma real transformação ao turismo que se quer "alternativo". Além disso, pode contribuir para uma experiência turística que estimule não só a fruição, mas também a reflexão do ecoturista ao visitar esses espaços - reflexão que deve ser pautada pela ação educativa e aqui ressaltamos a EA crítica. Dessa forma, podemos entender que a ecologia profunda oferece ao ecoturismo bases para se constituir como uma prática que estimule uma reconexão e uma reflexão sobre a natureza pautada por princípios éticos fundamentados.

Ademais, lembramos que em nossa discussão inicial, estabelecemos que a atividade turística não pode ser desvinculada do mundo do trabalho e que se apresenta, por suas características, como uma forma de lazer moldada a partir da produção (CORIOLANO, 2006, p.217). Dessa maneira, todas as práticas de turismo, incluindo o ecoturismo, apresentam-se também em sua dimensão econômica"21, ou seja, como "uma atividade econômica e dinâmica, sobre a qual incidem múltiplos interesses" (BRASIL, 1994, p.33). Por isso, precisamos abordar também as relações dessa dimensão à prática do ecoturismo.

Segundo Pires (2002, p.140-141), os diversos setores de interesse (meio acadêmico, área governamental, organizações não-governamentais, público, mídia, etc.) concebem "sua própria ideia de ecoturismo em função da sua relação e de seus interesses mediatos e imediato sobre o tema, dando vazão a diferenciadas acepções e com elas apegando-se a distintos conceitos que se formulam sobre ele". Assim sendo, precisamos tratar também a apropriação do termo "ecoturismo" pelo mercado turístico, ou seja, a rotulação de certas atividades como práticas ecoturísticas, principalmente pelo trade turístico. Segundo a literatura (PIRES, 2002; GOMES, 2003; HINTZE, 2008), é inegável que há uma clara disparidade entre a concepção do ecoturismo (pela literatura) e sua prática enquanto atividade econômica (pelo trade).

O turismo como fenômeno moderno associa-se intimamente ao lazer e, por isso, remete também ao prazer e permeia o imaginário humano que anseia pela liberdade, pelo divertimento, pelo gozo e que são representados a partir de ideias, símbolos, sonhos (CORIOLANO, 2006). Dessa maneira, no ecoturismo esses símbolos e ideias criados pelo imaginário humano ambientam-se no cenário natural e são reforçados pelo mercado turístico a fim de atrair o indivíduo interessado pelo contato com a natureza.

Por conseguinte, o anseio por atividades na natureza vem crescendo também por nossas condições de vida, onde nos encontramos imersos no mundo urbano, em seus trabalhos fatigantes e maçantes e em sua rotina desmotivadora. Mediante esse sentimento contemporâneo de mal-estar ou artificialidade das vidas cotidianas, a prática ecoturística, da forma como é constituída pelo mercado, abre espaço para o reencantamento pela natureza. 
Isso acontece a partir da resignificação do mundo natural como lugar de harmonia e sossego que possibilita "recarregar as energias" ou o encontro consigo mesmo (DIEGUES, 2001).

Destarte, percebemos que a concepção de ecoturismo utilizada amplamente pelo mercado apresenta-o como uma prática "com enfoque para a utilização da natureza apenas como meio ou cenário para sua realização e que oferecem aos turistas tão-somente a oportunidade de conhecer lugares e populações exóticas" (PIRES, 2002, p.160). Neste sentido, entendemos que, concebida deste modo, a atividade reforça e oferece amparo para a visão da natureza "bela e boa". Todo esse contexto apoia-se na visão romântica do mundo natural como lugar de admiração à magnitude da natureza intocada como representação do "paraíso perdido" de paz e harmonia (DIEGUES, 2001). Segundo Hintze (2008), essa construção privilegia uma visão superficial e idealizada da natureza, onde o ecoturismo apresenta-se como mercadoria e espetáculo.

De acordo com Diegues (2001), a ideia de "paraíso perdido" compõe na atualidade um neomito (ou mito moderno) ${ }^{22}$. Esse neomito justifica a seleção de espaços com atributos ecológicos e estéticos desejáveis para o "uso" e até mesmo conservação. Além disso, a partir dessa concepção, excluem-se da realidade ecológica suas relações com os aspectos sociais, políticos e culturais (DIEGUES, 2001), apresentando, portanto, uma noção superficial e fragmentada da natureza, transformando-a em espetáculo (HINTZE, 2008).

Assim sendo, essa visão reduz e simplifica a complexidade das questões ambientais. Com isso, percebe-se, então, que o mercado aborda as questões presentes nos fundamentos do ecoturismo sem qualquer aprofundamento ou questionamento crítico (HINTZE, 2008). Além disso, reproduz uma visão que expressa o entendimento da humanidade e natureza como diferentes e até opostos. Dessa forma, acaba não contribuindo para 0 surgimento de uma consciência ecológica, visto que não engendra nenhuma reflexão, apenas reproduz uma imagem idealizada da natureza como refúgio. Ademais, todo esse contexto retrata um quadro de apropriação e consumo da natureza, que é transformada em mercadoria e, assim, pasteuriza ou destrói as singularidades dos lugares a fim de torná-los "atraentes" (GOMES, 2003).

Dessa forma, o discurso utilizado pelo mercado é dotado de caráter oportunista, visto que na maioria das vezes, esses atores não se preocupam com as premissas da prática e utilizam-se da "ecologização" meramente como forma de tornar seus negócios ou projetos atrativos (PIRES, 2002, p. 163). Essa rotulação (ou auto-rotulação) "ecoturística" realizada pelo trade busca apenas otimizar sua lucratividade e contribui para transformar a prática em um "aperfeiçoamento mercadológico" do turismo de massas (GOMES, 2003). Dessa forma, a inserção do ecoturismo no mercado (ou a apropriação mercadológica da prática ecoturística) se apresenta como um grande desafio para sua concepção como veículo da educação ambiental crítica. Isso porque, como discutido concebido nos moldes retratados, a prática apresenta pouca ou nenhuma preocupação com o seu potencial educativo. 
Entretanto, não podemos negar que o ecoturismo é muito destacado pelo seu papel educativo e, na prática ecoturística, "uma grande ênfase recai sobre a apreciação, a educação e a interpretação da natureza" (WEARING; NEIL, 2001, p.12). Neste sentido, o ecoturismo é entendido como um veículo que possibilita a prática da educação ambiental não-formal.

Segundo Gohn (2014), usualmente, a educação não-formal é definida apenas pela sua negação, pelo que não é (ou seja, formal). Neste sentido, torna-se importante defini-la pelas suas características próprias e, dessa forma, a autora define a educação não-formal como "[...] um processo sociopolítico, cultural e pedagógico de formação para a cidadania, entendendo o político como a formação do indivíduo para interagir com o outro em sociedade" (GOHN, 2014, p. 40). Segundo a autora, essa prática educativa não formal envolve também a intencionalidade no ensino, ou seja, não acontece a partir de um processo espontâneo, por isso, é necessário que seja pautada por um conjunto de práticas socioculturais de aprendizagem e produção de saberes.

No âmbito brasileiro, a EA não-formal é contemplada na Política Nacional de Educação Ambiental (Lei 979532 de 27/04/99) e, segundo esta política, uma das formas de abordagem da EA não-formal é o ecoturismo (BRASIL, 1999, p. 6). Dessa forma, reconhece-se a relação entre a educação ambiental não-formal e o ecoturismo. Portanto, entendemos que a possibilidade educativa do ecoturismo se apresenta no contato direto do sujeito com o meio natural, que é componente indispensável para prática ecoturística. Dessa forma, ao estar em um ambiente natural, o domínio afetivo das pessoas é afetado e, havendo o direcionamento para o aprendizado e a sensibilização, é possível então unir esse domínio afetivo ao cognitivo para criar uma experiência que privilegie a educação (MENDONÇA; NEIMAN, 2002).

Por conseguinte, entende-se que ao se abrir e se dispor a adentrar um espaço com predomínio de aspectos físicos naturais, um espaço novo e diferente do que se está acostumado, o visitante se coloca em uma situação de vulnerabilidade. Assim, colocando-se perante o desconhecido, esse visitante se propõe a enfrentar desafios. Dessa maneira, segundo Mendonça e Neiman (2002), esses momentos possibilitam ao sujeito situações de enfrentamentos, onde é possível se conhecer melhor e conhecer também o outro que, neste sentido, pode ser o meio natural ao seu redor ou seu próximo. Assim, nosso corpo e nossas emoções se tornam mais acessados e acessíveis e podemos nos abrir para novas oportunidades (MENDONÇA; NEIMAN, 2002).

Portanto, nesse momento de enfrentamento, quando a possibilidade de autoconhecimento se apresenta, também podemos encontrar uma oportunidade para 0 aprendizado. Nesse instante de contemplação e superação temos a possibilidade de mudança e ruptura com nosso modo de vida e seus valores, que nos afastam da nossa condição animal/natural (HINTZE, 2008). Assim sendo, esses momentos tornam-se fecundos para questionamentos e reflexões. É por isso que devem ser pautados pelo diálogo, pela interação e, assim, ir além da transmissão de informações e 
conteúdo - além das falas repetitivas que, de certa forma, privam tais momentos de seu caráter não-formal, assim como das suas possibilidades de transformação.

Destarte, a imersão nos ambientes menos alterados pela urbanização evoca nos sujeitos ali presentes a possibilidade de um novo olhar sobre " 0 mundo que ele vive e pelo qual é responsável" (CARVALHO, 2008, p.156). Nesse sentido, é importante ressaltar que para que esse novo olhar, essa nova postura, se concretize é premente que um programa educativo seja implementado. Dessa forma, destacamos a necessidade de uma "estratégia educativa [que] deve ser bem planejada, [que] requer estudo, fundamentação e constante revisão de sua prática" (HINTZE, 2008, p.82), ou seja, da intencionalidade educativa tratada por Gonh (2014). Assim, o caráter "nãoformal" da EA deve ser entendido como terreno de flexibilidade, mas não de descomprometimento. Por isso, evidenciamos que a educação não-formal é uma prática legítima que necessita ser discutida, planejada, fundamentada teoricamente e avaliada em sua prática (GOHN, 2014).

Portanto, o papel da educação ambiental não-formal na prática ecoturística também deve ser tratado com essa mesma centralidade e seriedade. Assim, para que a prática ecoturística se concretize como possibilidade educativa, o contato com a natureza interior e exterior deve sempre ser instigador de uma reflexão mais profunda. Essa reflexão deve ser permeada pela complexidade das questões socioambientais abordadas pela perspectiva da EA crítica, ou seja, permeada por uma "atitude de investigação atenta, curiosa, aberta à observação das múltiplas inter-relações e dimensões da realidade" (CARVALHO, 2008, p.130). Esses elementos são essenciais para que as possibilidades da educação ambiental não-formal na prática ecoturística possam ser concretizadas

\section{O ecoturismo deveria se preocupar com a formação de sujeitos ecológicos?}

Conforme tratamos ao longo deste trabalho, a "questão ambiental" destaca-se na cena pública atualmente e tem estimulado debates sobre as relações da sociedade com o mundo entendido como natural. O panorama contemporâneo de mal-estar perante a vida urbana conturbada tem impulsionado o desejo de "retorno à natureza" e, dessa maneira, as viagens a ambientes pouco alterados pela vida humana têm sido muito procuradas e discutidas. A partir dessa constatação, procuramos estabelecer as relações entre a prática ecoturística como visita a esses espaços e a educação ambiental, que aliadas buscam construir no sujeito uma postura consciente perante tais ambientes. Ressaltamos aqui que nossa relação sociedadenatureza é resultado de uma construção histórica e social e que essas raízes se sustentam em cenários construídos com uma intenção, com um sentido. Assim sendo, precisamos lembrar que, como humanos, poderíamos ter seguido outro(s) caminho(s) e, portanto, poderíamos ter construído outra(s) relação(ões) com a natureza da qual pertencemos. Entretanto, forças estruturais e conjunturais de nossa sociedade moderna ocidental atuaram para reforçar a hegemonia de um caminho que se tornou, então, dominante. 
Dessa forma, esse trabalho buscou destacar a formação do sujeito (ecológico) como possível força de resistência, como possibilidade de construção de novos caminhos no que concerne a relação sociedadenatureza. Assim, entendemos que a formação de si como sujeito representa uma força capaz de responder às imposições e pressões vividas pelo indivíduo na contemporaneidade. Neste contexto, o sujeito emerge como resistência à nossa sociedade de consumo, que se impõem cada vez mais sobre ele. Assim sendo, o sujeito apoia-se em sua experiência vivencial a fim de construir algum "sentido" perante o movimento incessante de nossas vidas contemporâneas. Entendemos, assim, que é uma construção constante, um trabalho diário, portanto, um esforço ativo que se sedimenta no coletivo. Nesta perspectiva, a formação de si como sujeito exige a consciência de que sua ação deve ser coletiva e, portanto, a sua associação ao outro e seu apoio em outros sujeitos é essencial para sua própria formação. Essa formação é árdua e só é possível através da "escola do sujeito" (TOURAINE, 1998) ou, também poderíamos dizer, pela educação crítica.

É a partir da centralidade da educação para a formação do sujeito, que tratamos o sujeito ecológico pela visão da educação ambiental crítica. Essa visão enfatiza o papel da educação como caminho para a formação humana crítica (CARVALHO, 2008). Essa concepção da educação ambiental crítica ampara-se muito na pedagogia freireana, em que a nossa percepção e vivência do mundo é compreendida como permeada por nossas experiências pessoais - pelos nossos contextos sociais, políticos e culturais de vida. Dessa forma, essa prática educativa busca ir além da transmissão de dados, fatos, informações, entre outros. A referida prática busca formar um sujeito que, ao receber tais informações, consiga principalmente refletir criticamente sobre elas.

Assim, superar uma leitura única do mundo, ampliar as realidades, abrir o olhar para as diversidades é a função principal da ação educativa que se propõe crítica. Para isso, o educando deve ter a possibilidade de ser parte desse aprendizado através do diálogo aberto, deve poder se inserir como sujeito ativo nessa relação. Por isso, reconhecer o educando como sujeito crítico e formá-lo para "o mundo" contribui para conscientizá-lo e, assim, enriquece a prática educativa para que seja voltada não só para a "sala de aula", mas também para a transformação do mundo. É nesse sentido que a EA crítica busca promover a formação do sujeito ecológico, ou seja, contribuir para a formação de um sujeito que adota atitudes ecológicas no mundo, mas também reflete sobre o mundo e sobre si mesmo nesse mundo (CARVALHO, 2008).

É comum dizermos que nos importamos com questões que são próximas de nós e, se essa afirmação é verdade, entendemos, então, que é pelo interesse - que muitas vezes emerge no âmbito pessoal - que podemos nos abrir para o engajamento em causas públicas e de âmbito coletivo. É nesse sentido que o ecoturismo como prática que acontece no "mundo da vida" (GOHN, 2014), ou seja, em contato com a experiência na e da natureza - que inclui a natureza interna do mesmo - pode se apresentar como atividade promotora da EA crítica não-formal. Isso significa dizer que a prática do ecoturismo, o contato direto com ambientes físicos naturais, a 
experiência e os desafios encarados nesses momentos de abertura para o desconhecido são momentos ricos para o aprendizado, visto que possibilitam unir o domínio afetivo e cognitivo da prática educativa (NEIMAN, 2007).

Assim, entende-se que as visitas à natureza durante a prática do ecoturismo podem abrir as portas para a reflexão, porque abrem as portas para outro(s) mundo(s) que se encontra $(m)$, atualmente, distante de nós. Esse momento de interação possibilita novas sensações, emoções e reações no sujeito e deve ser pautado pela reflexão crítica. Por conseguinte, só há possibilidade de reflexão quando há a intencionalidade educativa, que no caso do ecoturismo fundamenta-se pela EA não-formal. Dessa maneira, apesar de relevante e importante, esse contato com a natureza na prática ecoturística precisa superar o aspecto contemplativo ou místico.

Dessa forma, estabelecido em ambientes "não-formais", o ecoturismo pode ampliar as possibilidades educativas, no sentido de libertar o sujeito de ambientes "duros" e situações desinteressantes e até mesmo tediosas, afinal, aprendemos melhor quando nos sentimos bem. Assim, pensamos, então, quais as possibilidades de reflexão realmente concretas quando a prática não se pauta por uma intencionalidade educativa? Acreditar que um processo de sensibilização, conscientização ou formação acontecerá de maneira espontânea é coerente, se considerarmos as questões abordadas aqui?

Ademais, percebemos ainda que, nos casos em que a intencionalidade educativa se apresenta, a prioridade nas atividades de EA durante a prática do ecoturismo é a propagação de comportamentos "ambientalmente corretos", ou seja, uma herança da educação ambiental conservacionista. Isso mostra a hegemonia de tal vertente e, neste sentido, aponta também a hegemonia da prática educativa entendida como transmissão de informações e dados.

Entendemos que uma "receita" de passos corretos para se tornar (ou se autoproclamar) um sujeito ecológico (ou um ecoturista), por exemplo, não leva ninguém a sê-lo, porque sua construção passa pela formação crítica, assim como a construção de uma atitude ecológica envolve a mudança do modo de pensar e sentir desse sujeito no mundo e não apenas no ambiente com predomínio de aspectos físicos natural. Dessa maneira, essa abordagem hegemônica também demonstra uma fragmentação entre as esferas que permeiam a "questão ambiental" (ecológico/social/político). Assim, há uma negligência das interrelações e complexidades presentes nessa temática, fato que só faz crescer o abismo entre homem (cultura) e natureza, sendo que humano é natureza (CARVALHO, 2008).

Sendo assim, se o ecoturismo busca contribuir para superação de uma imagem contemplativa do mundo natural e ressaltar o valor intrínseco deste, não deveria privilegiar uma abordagem educacional que englobe 0 ser humano como natureza? Se nos inserimos ao mundo natural, trabalhamos para reconhecê-lo como nosso igual e, assim, podemos contribuir para quebrar a ideia de "superioridade humana" ou da natureza como "utilitária" muito difundida na atualidade. Para clarificar essa relação entre cultura/natureza na experiência do indivíduo, lembramos aqui Brandão (2002 apud CARVALHO, 2008, p. 86), quando afirma que "Eu [humano] me vejo 
como um ser da natureza, mas me penso como um sujeito da cultura". Só a partir dessa visão que o ecoturismo poderia contribuir para a adoção de atitudes ecológicas.

As raízes de acontecimentos ou relações que construímos dizem muito sobre o que elas se tornam. Nossa relação humana com o mundo natural traz uma herança de distanciamento, que aliada a outros elementos (cristianismo e Revolução Científica, por exemplo), levou a uma ruptura entre humano e natural. Podemos perceber, então, que de certa maneira essa ruptura encontra-se presente até hoje na abordagem conservacionista da EA. É justamente essa ruptura, esse distanciamento que a EA crítica busca reconhecer e trabalhar para superar. Por tudo isso, entendemos que se 0 ecoturismo busca se apresentar como uma prática alternativa, se almeja se afirmar como uma prática voltada para a educação e deseja contribuir para conservação do mundo natural que vivencia, assim como para a sensibilização dos sujeitos praticantes deveria, para isso, se preocupar com a formação dos sujeitos, sujeitos conscientes de si, de sua natureza interior e da natureza exterior, sujeitos ecológicos.

Esse caminho possibilita inclusive, como buscamos demonstrar, identificar as contradições presentes na realidade da prática ecoturística, porque privilegia a formação crítica e ativa. Não podemos negar que o olhar atento ao mundo nos mostra que a maneira como o ecoturismo se configura atualmente é passível de diversas problematizações. A mercantilização e espetacularização da natureza pelo ecoturismo são realidades que não podem ser ignoradas e que precisam ser combatidas (HINTZE, 2008). Assim, romantizá-lo contribui para reforçar (reafirmar) esse lamentoso quadro. Tentamos mostrar que dissociado da ação educativa crítica, a prática ecoturística acaba por transformar-se em mera mercadoria e se desfaz tanto pelas pressões do mercado quanto pelas posturas acríticas do indivíduo (também pressionado) e acaba por gerar justamente o oposto do que sua "possibilidade" representa. Portanto, sem a valorização ou compreensão sobre o papel da educação não-formal e sem o direcionamento crítico da EA, a atividade torna-se limitada e reprodutiva.

Dessa forma, destacamos a necessidade da valorização da educação não-formal como parte legítima da formação educativa, assim como a importância de sua difusão e de estudos que contribuam para afirmar sua validade como abordagem de aprendizado. Muitas vezes, diminui-se a relevância dessas práticas educativas, como se não aprendêssemos na vida, como se não aprendêssemos pelas nossas experiências. De certa maneira, isso também pode ser dito sobre a educação ambiental, quando é reduzida a atividades que priorizam o ensino institucionalizado, formal ou a transmissão de informações e conhecimentos "corretos", "científicos", "oficiais" e descartase, assim, sua rica abordagem dialógica, reflexiva, interacional. Apenas a partir dessa abordagem pode-se estimular o indivíduo pressionado e imerso em nossa sociedade de consumo a abrir seus olhos e atender ao desafio de formar-se como sujeito.

Ademais, ressaltamos que é importante contextualizar o peso, a dimensão das problemáticas que se apresentam em nossa vida 
contemporânea. Ao tratarmos do papel do sujeito ecológico e da importância da atitude ecológica, estamos enfatizando sua relevância para a ação coletiva. Sua razão de existir é primeira e antes de tudo, sua capacidade de situar o sujeito criticamente perante as problemáticas e conflitos socioambientais existentes. Dessa forma, destacamos que a intenção não é atribuir ao sujeito o papel de herói ou salvador, como se toda a complexidade da questão socioambiental discutida até aqui dependesse exclusivamente da postura individual desses sujeitos. O que buscamos é enfatizar a força do sujeito para a ação coletiva, sua importância utópica em contribuir para a criação e/ou continuidade de ações necessárias e, inclusive, para servir de inspiração aos que se dispõe a agir para a mudança, ou seja, sua inspiração para outros e outras também se constituírem como sujeitos ativos e críticos.

Por conseguinte, evidenciamos ainda que, de certa forma, o mesmo pode ser destacado a respeito da prática educativa em si, que precisa ser entendida como essencial. Porém, não pode ser vista como única salvadora ou redentora das complexidades, conflitos e crises combatidas em nossa sociedade. É preciso admitir que diversas conjunturas e meios (economia, religião, política, comunicação, ciência, etc.) exercem também sua influência na existência e atuação do sujeito no mundo e, portanto, precisamos também reconhecer suas limitações e trabalhar na superação de uma visão ingênua da ação educativa (CARVALHO, 2008).

Por último, encaminhamos alguns incômodos surgidos ao longo deste trabalho, algumas questões que achamos importante destacar: se a ação educativa crítica e não-formal pode ser trabalhada na prática ecoturística, se ela pode acontecer e contribuir para a formação de sujeitos ecológicos, por que esse processo não acontece? Ou se estamos sendo mais otimistas, por que acontece tão raramente? Dessa forma, perguntamos: o que o ecoturismo (ou seus defensores) traz como preocupação no "papel" é realmente o que ele prioriza em sua prática? Assim, para pensarmos em um ecoturismo que possa ser verdadeiramente uma possibilidade educativa, precisamos pensá-lo também como uma atividade educativa não-formal $\mathrm{e}$, por conseguinte, devemos pensar a educação não-formal como prática legítima e necessária.

Ademais, não podemos deixar de reconhecer as inconsistências e conflitos inseridos na prática, afinal, ecoturismo é ainda turismo. Por isso, entender a origem dessa atividade é essencial para admitir suas problemáticas e caminhar em direção a alternativas que tragam uma visão crítica de sua condição. A verdade é que somos constantemente desafiados e, muitas vezes, nos sentimos descrentes seja pela pressão, impotência ou até acomodação. É nesse sentido, então, que o ideário utópico que constitui o sujeito ecológico pode se apresentar como uma força de ação e inspiração. Afinal, somos sujeitos do mundo, não apenas sujeitos da escola, do âmbito acadêmico ou do mercado de trabalho.

Dessa maneira, a partir dessas indagações percebidas durante a construção desse trabalho, ressaltamos que ele foi concebido com o intuito de contribuir para uma discussão bem recorrente e necessária e que, portanto, apresenta-se como um esforço ainda inicial. Por isso, reforçamos e desejamos que outras contribuições, ações e também novas pesquisas sejam 
direcionadas para o tema aqui abordado a fim de caminharmos ainda mais na construção de sujeitos do mundo.

\section{Referências}

BARRETTO, M. Manual de Iniciação ao estudo do turismo. Campinas, SP: Papirus, 2014.

CARVALHO, I.C.M. Educação ambiental: a formação do sujeito ecológico. São Paulo: Cortez, 2008.

CORIOLANO, L.N.M.T. O turismo nos discursos, nas políticas e no combate à pobreza. São Paulo, Annablume, 2006.

DIEGUES, A.C.S. O mito moderno da natureza intocada. São Paulo: Hucitec, 2001.

ESTEVA, G. Desenvolvimento. In: SACHS, W. (org.). Dicionário do desenvolvimento: guia para o conhecimento como poder. Petrópolis, RJ: Vozes, 2000.

FENNELL, D.A. Ecoturismo. São Paulo: Contexto, 2002.

FREIRE, P. Pedagogia da autonomia: saberes necessários à prática educativa. São Paulo: Paz e terra, 1996.

GIL, A.C. Métodos e técnicas de pesquisa social. São Paulo: Atlas, 6 ed., 2008.

GOHN, M.G. Educação Não Formal, Aprendizagens e Saberes em Processos Participativos. Revista Investigar em Educação, 2 ${ }^{a}$ Série, n. 1, 2014.

GOMES, P.M. (Eco)turismo: uma (re)leitura dos discursos. Brasília: Ibama, 2003.

HINTZE, H.C. Ecoturismo na cultura do consumo: possiblidade de educação ambiental ou espetáculo? Dissertação (mestrado) - Universidade de São Paulo, Escola Superior de Agricultura Luiz de Queiroz. 137 p., 2008.

KRIPPENDORF, J. Sociologia do Turismo: para uma nova compreensão do lazer e das viagens. São Paulo: Aleph, 2001.

LIMA, G.F.C. Educação ambiental crítica: do socioambientalismo às sociedades sustentáveis. Educação e Pesquisa, São Paulo, v.35, n.1, p. 145-163, jan./abr. 2009.

LOUREIRO, C.F.B. Educação ambiental crítica: contribuições e desafios. In: MELLO, S.S. (org.), TRAJBER, R. (org.). Vamos cuidar do Brasil: conceitos e práticas em educação ambiental na escola. Ministério da Educação, Coordenação Geral de Educação Ambiental: Ministério do Meio Ambiente, Departamento de Educação Ambiental: UNESCO, 2007.

MENDONÇA, R.; NEIMAN, Z. Ecoturismo: discurso, desejo e realidade. In: NEIMAN, Z. (Org.). Meio ambiente, educação e ecoturismo. Baueri, SP: Manole, 2002. 
NEIMAN, Z. A Educação Ambiental através do contato dirigido com a natureza. Tese (doutorado) - Universidade de São Paulo, Pós-Graduação em Psicologia. 138 p., 2007.

OURIQUES, H.R. A produção do turismo: fetichismo e dependência. Campinas, SP: Alínea, 2005.

PANOSSO NETTO, A. Filosofia do turismo: teoria e epistemologia. São Paulo: Aleph, 2005.

PIRES, P.S. Dimensões do ecoturismo. São Paulo: editora SENAC São Paulo, 2002

SANTOS, B.S. Um Discurso sobre as Ciências. Edições Afrontamento: Porto, 1988.

TOURAINE, A. Crítica da Modernidade. Petrópolis, RJ: Vozes, 1994.

TOURAINE, A. Poderemos Viver Juntos? Iguais e Diferentes. Petrópolis, RJ: Vozes, 1998.

WEARING, S.; NEIL, J. Ecoturismo: impactos, potencialidades e possibilidades. São Paulo: Manole, 2001.

\section{Notas:}

${ }^{1} O$ presente artigo é decorrente da monografia de conclusão de curso intitulada "Ecoturismo e Educação Ambiental: reflexões sobre a formação do sujeito ecológico".

${ }^{2}$ Lei 9.795/99 que "Dispõe sobre a educação ambiental, institui a Política Nacional de Educação Ambiental e dá outras providências", disponível em: $<$ http://www.planalto.gov.br/ccivil 03/leis/L9795.htm>.

3"Entende-se o tempo livre, portanto, como aquele vinculado ao trabalho, pois, se não houver o trabalho, o tempo não será livre, estará sempre desocupado. [...] Tempo livre de trabalho e tempo desocupado são tempos diferenciados. No primeiro, o trabalho não está presente, mas remunera esse tempo; no segundo, o tempo é todo desocupado sem trabalho e sem remuneração. O primeiro pode ser direcionado ao turismo, o segundo não, apenas ao lazer" (CORIOLANO, 2006, p. 27).

${ }^{4}$ Dentre as consequências (impactos negativos) causadas pela massificação do turismo podemos citar: "expropriação e ocupação violenta do território por parte das forças e agentes turísticos; especulação imobiliária e da terra; expulsão e marginalização de populações locais; ruptura dos valores culturais e desequilíbrio da economia local; degradação de culturas tradicionais; manipulação da memória e da herança coletiva; violação de lugares sagrados; segregação étnica; formação de "guetos" turísticos; desvios de comportamento e prostituição de mulheres e adolescentes; comportamento grosseiro e insensível de turistas nos destinos estrangeiros; poluição e destruição do meio natural; imperialismo econômico de corporações transnacionais, neocolonialismo; evasão de divisas para o exterior" (PIRES, 2002, p. 35).

5"O desenvolvimento sustentável é aquele que atende às necessidades do presente sem comprometer a capacidade das gerações futuras de atenderem as suas próprias necessidades. Ele contém dois conceitos-chave: o conceito de 'necessidades, sobretudo as necessidades essenciais dos pobres do mundo, que devem receber máxima prioridade; a noção das imitações que o estágio da tecnologia e da 
organização social impõe ao meio ambiente, impedindo-o de atender às necessidades presentes e futuras"' (NOSSO FUTURO COMUM, 1991, p.46).

${ }^{6}$ Segundo Pires (2002) a associação da sustentabilidade relaciona-se principalmente ao desenvolvimento do ecoturismo e tem como marco a Eco-92, no Rio de Janeiro.

${ }^{7}$ Segundo Pires (2002) estes eventos foram: em Washington-EUA, o Seminário sobre Impactos Sociais e Culturais do Turismo (1976); em Manila-Filipinas, a Conferência da OMT (1980); em Bangcoc-Tailândia, a Comissão Ecumênica em Turismo do Terceiro Mundo (1981); na Ásia, o Seminário sobre Turismo Alternativo (1984); na Alemanha, um evento sobre a construção de uma nova ordem de turismo (1986); na Polônia, o Primeiro Encontro sobre Perspectivas Teóricas em Formas Alternativas de Turismo (1989); em Tamanrasset - Argélia, o Seminário sobre Turismo Alternativo da OMT (1989).

${ }^{8}$ Ver MIECZKOWSKI, Z. Environmental issues of tourism and recreation. University Press of America, Inc: Latarn, Maryland, 1995.

${ }^{9}$ Segundo Carvalho (2008), a educação ambiental crítica representa uma nova orientação pedagógica da EA, que busca se fundamentar como um projeto político pedagógico com raízes nos ideais emancipadores da educação popular e posições teórico-metodológicas orientadas por uma visão socioambiental e por uma visão compreensiva.

10“"...] denominada compreensiva, em contraposição à pretensão explicativa da racionalidade objetificadora, e para a qual a verdade não é absoluta nem reside em uma ordem natural preestabelecida. Essa racionalidade compreensiva, fruto da crítica e da crise do paradigma moderno, busca superar as dicotomias entre natureza e cultura, sujeito e objeto, a fim de compreender a realidade como fruto do entrelaçamento desses mundos" (CARVALHO, 2008, p. 118).

${ }^{11}$ Segundo o autor, são dois temas de reflexão epistemológica que trazem à tona essas limitações do paradigma científico moderno. O primeiro ressalta que "são questionados o conceito de lei e o conceito de causalidade [...] a simplicidade das leis constitui uma simplificação arbitrária da realidade que nos confina a um horizonte mínimo para além do qual outros conhecimentos da natureza, provavelmente mais ricos e com mais interesse humano, ficam por conhecer. [...] a relativização do conceito de causa parte sobretudo do reconhecimento de que o lugar central que ele tem ocupado na ciência moderna se explica menos por razões ontológicas ou metodológicas do que por razões pragmáticas" (SANTOS, 1988, p. 11). O segundo "versa mais sobre o conteúdo do conhecimento científico do que sobre a sua forma. Sendo um conhecimento mínimo que fecha as portas a muitos outros saberes sobre o mundo, o conhecimento científico moderno é um conhecimento desencantado e triste que transforma a natureza autômato [...] Este aviltamento da natureza acaba por aviltar o próprio cientista na medida em que reduz o suposto diálogo experimental ao exercício de uma prepotência sobre a natureza" (SANTOS, 1988, p. 11).

${ }^{12}$ Boaventura Santos (1988) apresenta o conjunto de teses que formam esse novo paradigma, sendo eles: "1. Todo o conhecimento científico-natural é científico-social"; "2. Todo o conhecimento é local e total"; "3. Todo o conhecimento é autoconhecimento"; "4. Todo o conhecimento científico visa constituir-se em senso comum". Ver: SOUSA SANTOS, B. Um discurso sobre as Ciências (1988).

${ }^{13}$ Existem também outras concepções de EA que se baseiam na perspectiva crítica, ou seja, "concretamente, a educação ambiental crítica se insere no mesmo bloco ou é vista como sinônimo de outras denominações que aparecem com freqüência em 
textos e discursos (transformadora, popular, emancipatória e dialógica)" (LOUREIRO, 2007, p. 66).

${ }^{14}$ Segundo Carvalho (2008) "este tipo ideal ou modo ideal de ser também se aproxima, nos termos da psicologia, do conceito "ideal de ego". O ideal de ego agrega aqueles valores e crenças familiares, sociais e culturais que constituem os traços e as marcas tidas como positivas e que vão constituir modelos para identificação no processo de subjetividade" (CARVALHO, 2008, p. 67).

${ }^{15}$ Ver TOURAINE, A. Crítica da Modernidade (1994) e Poderemos Viver Juntos? Iguais e Diferentes (1998).

${ }^{16} \mathrm{O}$ autor traz uma análise extensa e detalhada desses processos em seus livros, mencionados anteriormente.

17"O termo "comunitarismo" é utilizado sobretudo na língua francesa (a partir dos anos 1980), para designar, com uma intenção crítica, toda a forma de etnocentrismo, toda a autoconcentração de grupo que implica uma autovalorização e uma tendência ao fechamento sobre si, num contexto cultural dito "pós-moderno", onde a abertura, e mais particularmente a abertura ao outro, é fortemente valorizada - o que redefiniu a orientação "cosmopolita". Por outro lado, o "comunitarismo" é definido pelos seus críticos como um projeto sociopolítico que visa submeter os membros de um dado grupo às normas desse mesmo grupo (dessa tal "comunidade"), ou seja, a controlar as opiniões e os comportamentos de todos aqueles que pertencem em princípio à dita "comunidade". A tirania de tal "comunidade" constitui um fenômeno social observável. $O$ apelo à ordem comunitária, a injunção de 'deves pensar e viver à imagem da tua comunidade' é frequentemente lançada aos indivíduos que se entende tomarem 'demasiadas liberdades' em relação ao que é comunitariamente conveniente fazer e pensar" (TAGUIEFF, 2003, p. 1-2).

18“ Se o valor que se diz que algo tem é um meio para um determinado fim, então será designado que esse algo tem valor "instrumental" (WEARING; NEIL, 2001, p.17).

${ }^{19}$ Dentre as justificativas instrumentais para a preservação/conservação da natureza estão: seu valor por oferecer o despertar espiritual o deleite estético; seu valor por seu estoque de diversidade genética; seu valor para a pesquisa científica; seu valor para o turismo e a recreação (GODFREY-SMITH apud WEARING; NEIL, 2001).

20“[...] "o 'valor intrínseco' é valor que existe por seu próprio direito, por sua própria causa" (WEARING; NEIL, 2001, p. 17).

${ }^{21}$ Ressaltamos nesse ponto toda a discussão estabelecida anteriormente a respeito do fenômeno turístico, evitando assim, um posicionamento simplista e/ou reducionista. Dessa forma, enfatizamos novamente o entendimento do turismo como um "fenômeno multifacetado" que envolve "[...] conceitos econômicos, sociológicos, geográficos, antropológicos" (CORIOLANO, 2006, p.46), destacando assim a complexidade inerente a essa atividade.

${ }^{22}$ Ver O mito moderno da natureza intocada (2001). 
Patrícia Michelle Oliveira Freire: Universidade Federal de Minas Gerais, Belo Horizonte, MG, Brasil.

E-mail: pmofreire@hotmail.com

Link para o currículo Lattes: http://lattes.cnpq.br/9569674074107012

Fabiana Andrade Bernardes Almeida: Universidade Federal de Minas Gerais, Belo Horizonte, MG, Brasil.

E-mail: fabianabernardes@hotmail.com

Link para o currículo Lattes: http://lattes.cnpq.br/4337508057086972

Data de submissão: 29 de junho de 2018

Data de recebimento de correções: 06 de agosto de 2018

Data do aceite: 06 de agosto de 2018

Avaliado anonimamente 